\title{
Twins Cosmas and Damian - Patron Saints of Doctors
}

\author{
Witold Malinowski (ABCDF) \\ Department of Obstetrics and Pregnancy Pathology, Faculty of Health Sciences, Pomeranian Medical University in Szczecin, Poland
}

Corresponding Author: Witold Malinowski, Department of Obstetrics and Pregnancy Pathology, Faculty of Health Sciences, Pomeranian Medical University in Szczecin, Poland.

Received date: November 11, 2021; Accepted date: December 22, 2021; Published date: January 04, 2022

Citation: Witold Malinowski (2022). Twins Cosmas and Damian - Patron Saints of Doctors. J. Women Health Care and Issues. 5(1); DOI:10.31579/2642-9756/095

Copyright: (C) 2022 Witold Malinowski, This is an open access article distributed under the Creative Commons Attribution License, which permits unrestricted use, distribution, and reproduction in any medium, provided the original work is properly cited.

\section{Summary}

Saint Luke is the one commonly believed to be a patron saint of physicians. The less known are Cosmas and Damian, the only twin physicians to have been declared saints in the Catholic Church. In Poland, we have been recently observing a growing interest in these saint twins. This is mainly associated with a return to the tradition of the Apothecary Feast, celebrated on September 26, the day of Cosmas' and Damian's martyr death.

Key words: cosmas; damian; twins; history

\section{Introduction}

Saint Luke is the one commonly believed to be a patron saint of physicians. (He is called "beloved physician" by Saint Paul in his letter to Colossians 4:14: "Luke the beloved physician greets you...") [1]. However, Cosmas and Damian are less known, but also considered patron saints of doctors. They are surely the only twin doctors to have been declared saints in the Catholic Church (Figure. 1). The history has not left many reliable accounts of their life, most being legends and traditions with only some historical truth.

\section{History of the Twins - A Literature Overview}

Cosmas and Damian were born in the third century AD in Asia Minor, somewhere between Turkey and Syria, with some sources stating Mesopotamia as their birth place. Their father was a Greek pagan and died when the brothers were young children. Their mother Theodota, however, raised them in great piety. By her own example and by reading sacred scriptures to them, she raised her sons in accordance with the Christian faith. Thanks to her, Cosmas and Damian became devout Christians. When they became adults, they travelled to Syria, where they were trained in the art of medicine, which they subsequently practiced in Aegeae port (currently Ayash) in the Iskenderun Bay in Cilicia, Asia Minor. At present, this is a town in the southeastern Turkey in the Hatay province at the Iskenderun Bay at the base of the Amonos Mountains [2-5].

Cosmas and Damian were remarkably gifted and well-trained physicians. They cared for each person in need, particularly the poor. The possibility of helping and bringing relief in disease, not only to people, but also to animals, was a greater value for them than payment. They had excellent knowledge about various medications. They usually approached patients with words: "we only lay hands and can do nothing on our own, all is done by the almighty power and will of the Only True God and Lord Jesus
Christ; if you believe in Him, you will be shortly healed." By treating patients, they spread Christianity. They never accepted payment for their services, and therefore Eastern sources refer to them as anargyrami, from Greek Avó $\rho \gamma \nu \rho o$ ("without silver"), western sources call them "unmercenaries" ("treating for free"), and Orthodox sources "biessrebrennikami" (without silver coins, without money) [4,6,8]. This name denotes physicians who never accepted silver coins for their services. The twins believed that they owned everything thanks to God and strictly obeyed Jesus Christ's orders: "Heal the sick, raise the dead, cleanse those who have leprosy, drive out demons. Freely you have received; freely give." (Matthew 10:8) [7].

The name Cosmas is suspected to have originated from a Greek word kosmeo, meaning "I put in order" (or kosmos, meaning "order" or "universe"), while Damian is derived from Greek demios, meaning "a public doctor" [8]. The renown of Cosmas and Damian rapidly spread throughout the entire region. They were well-known, treated all who needed it, pagans included, which made many of them convert to Christian faith. Saladino d'Ascoli, an Italian physician who lived in the $15^{\text {th }}$ century, claimed that a medieval electuary, a pasty mass known as opopira ("fiery juice"), was invented by Cosmas and Damian. This medication was made from approximately 70 ingredients, including opium, mandrake, henbane, fragrant roots, resin, herbs and honey, and was usually administered mixed with wine in which herbs had been boiled. It was used for the treatment of various conditions, including mental disorders, paralysis, epilepsy, spasms, speech disorders and diseases of internal organs [9]. Cosmas and Damian treated and cared for patients without accepting any payment. This was their primary principle, which they never violated. Once, they were summoned to a severely ill woman, called Palladia, a wealthy Roman citizen, who had been denied treatment by all physicians due to her hopeless situation. Thanks to their medications, faith and earnest prayer, the woman was healed from a grave 
illness. According to the tradition "Palladia got up from her bed perfectly healthy and giving praise to God". "Palladia got up from her bed perfectly healthy and giving praise to God" As a token of gratitude for healing, she wanted to give the brothers a small gift and used a trick for this purpose. She approached Damian and handed him a small gift. The packaging contained three chicken eggs which, as she said, were to symbolize the Holy Trinity. Having heard the name of the Holy Trinity, pious Damian did not dare to refuse and accepted the gift taking it into his left hand and making the sign of the cross with his right hand. When Cosmas found out what had happened, he was offended, and no arguments convinced him that his brother had not broken the rules. Directly before his death, he instructed that his brother should not be buried beside him. After their martyr death, all wondered where Damian's tomb should be, but the available literature states that: "...they should have no doubts about whether to place Damian beside Cosmas, because Damian did not accept the eggs from the woman as payment, but out of respect for the Name of God" [2-4,11]. "A camel, which the saints had treated for its wildness, spoke with a human voice saying that... they should have no doubts about whether to place Damian beside Cosmas, because Damian did not accept the eggs from the woman as payment, but out of respect for the Name of God".

The great popularity of Cosmas and Damian and their considerable impact on people soon drew attention of Roman authorities. Soldiers were sent to capture the twins. Having heard about this, local Christians convinced Cosmas and Damian to go into hiding until they would help them escape. As the soldiers could not find the brothers, they arrested other Christians residing in the region. When Cosmas and Damian learnt about their capture, they decided to surrender and requested that the arrested Christians be freed. By the order of the Prefect of Cilicia Lysias, the brothers were imprisoned and tortured to force the act of apostasy. Stones, arrows, crucifixion and breaking wheel did not cause their death, though. According to a legend, they remained steadfast Christians until the very end of their lives. They died martyrs, probably on September 27287 AD (a different version recounts the date of August 23285 AD) in Cyrrhus (Kyrros), Syria, during the persecution of Christians under Emperor Gaius Aurelius Valerius Diocletianus. The twins were soon declared saints. The Catholic Church established a feast in their honor on the day of September 27, which was changed to September 26 in 1969. Their mother Theodota and their younger brothers Anthimus, Leontius and Euprepius, who had always supported them, also died a martyr's death for faith and were declared saints $[2-5,10]$. The sword with which Cosmas and Damian were beheaded, known in German literature as Zeremonialschwert or Prunkschwert (a ceremonial sword), was gifted to the nunnery in Essen by Emperor Otto III. This was a token of gratitude for the abbess for supporting Otto III in high fight for the throne with Henry the Quarrelsome. According to the tradition, this sword was used by Otto I in his victorious Battle of Lechfeld with Hungary on August 10 955. Apart from representative and ceremonial functions, the sword is traditionally considered a relic, a symbol of martyrdom of the abbey's patrons [11]. The city seal with the escutcheon with the said sword has been stored in Essen since 1473, which was again confirmed in 1483. Since then, the sword has been a part of the city's coat of arms. The inventory taken in the treasury of the Essen's cathedral in 1626 refers to the sword as Gladius sanctorum Cosmae et Damiani. The sword is still stored in this treasury [11]. It is a single-edged sword made of Damascus steel. It consists of a hilt with a guard and a long, rounded blade. The total length of the sword is $94 \mathrm{~cm}$, and the length of the blade itself is $80.5 \mathrm{~cm}$. The hilt is $13.5 \mathrm{~cm}$ long, the guard is $14 \mathrm{~cm}$ wide, and the scabbard is $82 \mathrm{~cm}$ long. The blade itself weighs $823.8 \mathrm{~g}$. The wooden, gilded scabbard (made probably of fruit wood) covered with a silver-plated sheet is entirely preserved. The ornamentation made using the repoussage technique forms zoomorphic motifs encircled by spiral twigs richly adorned with foliage (Figure. 2).

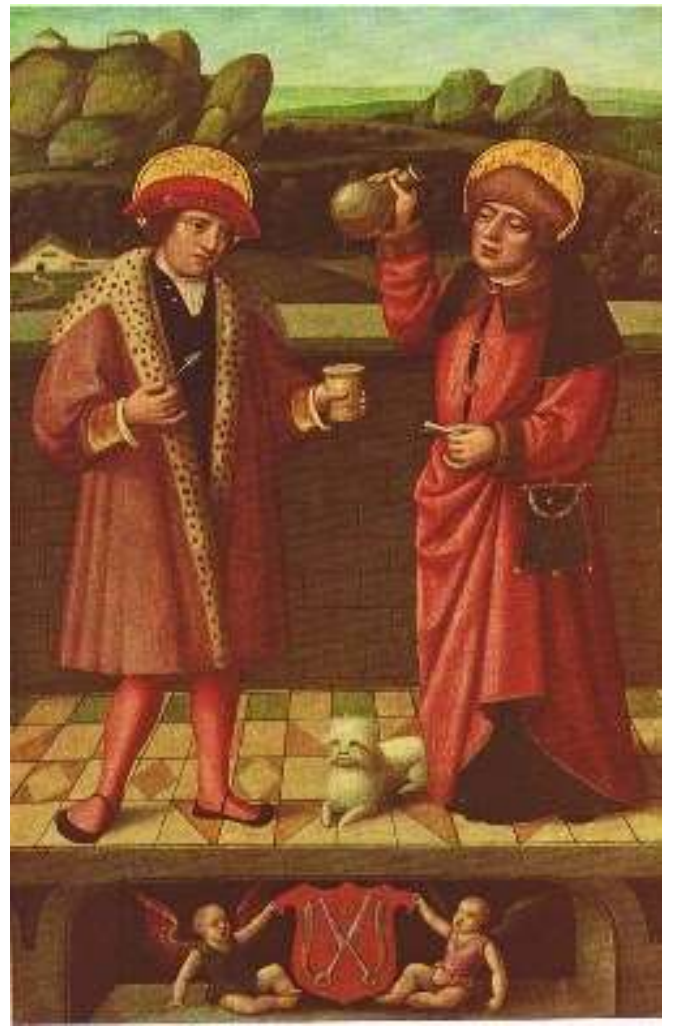

Figure. 2: Saints Cosmas and Damian, Flemish School, Adriaen Isenbrandt or Ambrosius Benson, 1540, Museum of the History of Pharmacy in Amsterdam.

The ceremonial nature of the sword is underlined in the letter to Romans: "For the one in authority is God's servant for your good. But if you do wrong, be afraid. They are God's servants, agents of wrath to bring punishment on the wrongdoer." (Romans 13:4) [12]. In the Middle Ages, a sword was a symbol of power and reign. Next to the crown, scepter and orb, it was the most important crowning insignia of monarchs. In the context of the Essen abbey, it represented a high status of nuns, who called themselves "princesses" up to secularization in 1803. The last princessabbess was Maria Kunigunde of the House of Wettin.

Another version recounts that after their arrest, Cosmas and Damian were taken to Rome, where they were imprisoned and brought to trial. They openly professed their faith and firmly refused making sacrifices to pagan gods saying "...we did no wrong to anyone, we are not involved in witchcraft or sorcery, which you accuse us of. We treat the ill with the help of our God and we take no payment for doing so as our Lord commanded his disciples: "Freely you have received; freely give." (Matthew 10:8). The emperor, however, kept demanding that they renounced their faith. In response to the twins' fervent prayer, God sent an illness upon Marcus Aurelius Carinus so that he, too, could experience the omnipotent power of God who does not forgive blasphemy against the Holy Spirit (Matthew 12:31: "And so I tell you, every kind of sin and slander can be forgiven, but blasphemy against the Spirit will not be forgiven"). In light of the then accounts, the Caesar probably suffered from torticollis, which prevented any head movement. Many people asked the brothers to heal the Caesar. He himself also begged and promised to convert to the true faith. The twins healed him. Cosmas and Damian were freed and returned home in glory. They could resume healing [2-4,6]. Unfortunately, what hatred of pagans and brutality of the Roman authorities could not do was done out of envy, one of the strongest passions of the human heart. An older physician, the twins' teacher, who trained them in the art of medicine, envied them their fame. He summoned 
the brothers, his former students, and asked them to gather some medicinal herbs with him. High in the mountains, as they were searching for herbs, the teacher murdered the twins and threw their bodies to the river $[2,3]$.

Tradition says that they were buried in Cyrrus (Kyrros), Syria. Their death was followed by many miracles. A man named Malchus, who lived at Thereman, near the church of Cosmas and Damian, went on a long journey, leaving his wife alone. He entrusted her to the protection of the brothers in his prayers. After some time, a stranger man appeared at her home claiming that Malchus had sent him to bring her to him. The woman believed and went with the man. He led her to a secluded place intending to kill her. Seeing the threat, the woman started crying to the brothers. At this moment, two wanderers appeared and defended her. The man let the woman go and fell off a cliff as he was trying to flee. The two wanderers led the woman home. When she asked them: "My rescuers, to whom I shall be grateful to the end of my days, what are your names?" They

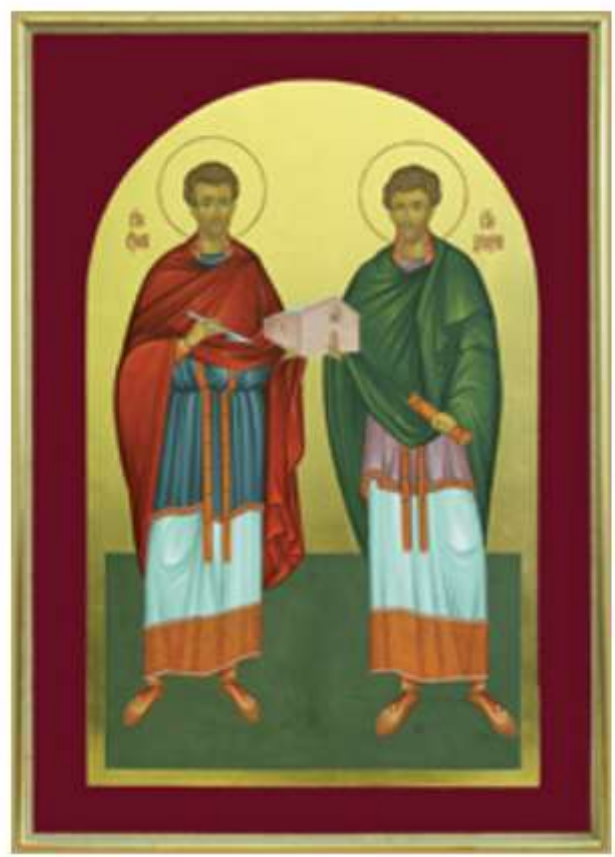

Until today, prayer to Saints Cosmas and Damian heal people of various illnesses. Prayers have been said in the case of smallpox, ocular diseases or leg illnesses and have also been offered for children with learning problems. Moreover, betrothed couples have also prayed to Cosmas and Damian.

The first churches dedicated to the saint twins were built in the $4^{\text {th }}$ century in Jerusalem, Egypt and Mesopotamia. In the $6^{\text {th }}$ century, their names were added to the Roman Canon (today the First Eucharistic Prayer in the liturgy of the Roman Rite). In Constantinople, Justinian the Great established, in the year 400 , two temples dedicated to the twins as he claimed to have been cured from a grave disease thanks to their intercession. This is also where two relics of the brothers, brought from Cyrus, were kept. Moreover Emperor Justinian I (527-565) and Archbishop Proclus built a magnificent basilica at the twins' grave, which answered: "We are the servants of Christ, Cosmas and Damian." "My rescuers, to whom I shall be grateful to the end of my days, what are your names?" They replied, "We are the servants of Christ, Cosmas and Damian," and became invisible.

From that time, the brothers were venerated as protectors of the sanctity and inviolability of Christian marriage, and as patrons of the harmony in conjugal life $[4,5]$.

Another legend says how Cosmas and Damian performed a miracle in the form of the world's first successful transplantation. A Roman deacon living in the $4^{\text {th }}$ century suffered from a severe illness in his leg and passionately prayed to Cosmas and Damian, pleading for help. One night, the brothers appeared at his bedside and transplanted a healthy leg from a recently deceased Ethiopian. The surgery was said to have been successful $[13,14]$. This has also been illustrated in iconography [Figure. 3].

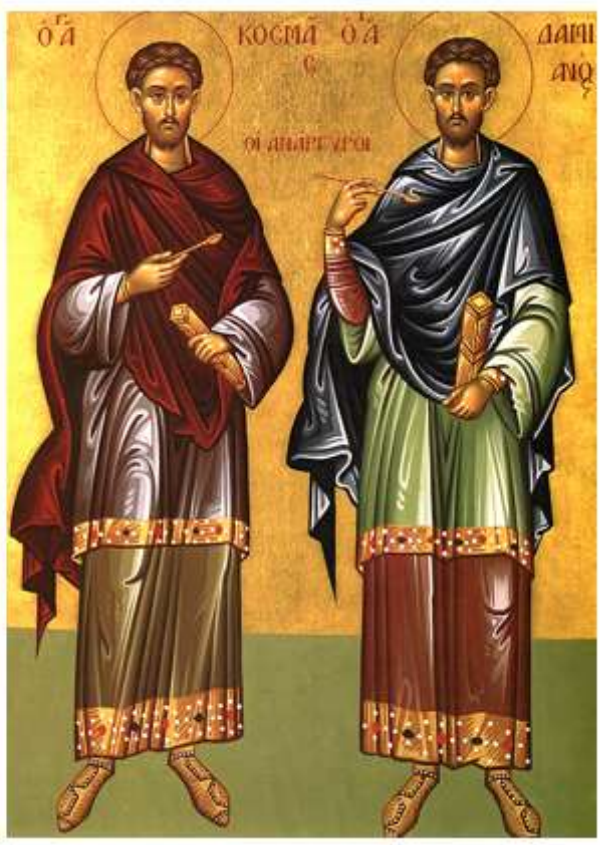

was a destination of multiple pilgrimages before Arabs and then Turks arrived. The city of Cyrrus was restored and devoted to the saint twins. Their cult spread rapidly and encompassed almost the whole world known at that time. In Rome, Pope Symmachus (498-574) built an oratory in their honor at the Santa Maria Maggiore Basilica, while Pope Felix IV (526-530) raised a church devoted to Saints Cosmas and Damian at the Forum Romanum, which is currently the primary place of their veneration. This is where a significant part of their relics can be found. The church is still known for its exquisite mosaic presenting the saint twins who, together with Saints Peter and Paul, are standing at both sides of Christ. The remaining relics are held in various parts of the world. They are particularly venerated at the cathedral church of Amalfi, in the southern Italy [5,6,10]. A fragment of the relic is also held in Poland: in the Orthodox Church in Bacieczki in Białystok. A piece of relic was brought from Kosovo in August 2009 [15,16] (Figure. 4). 


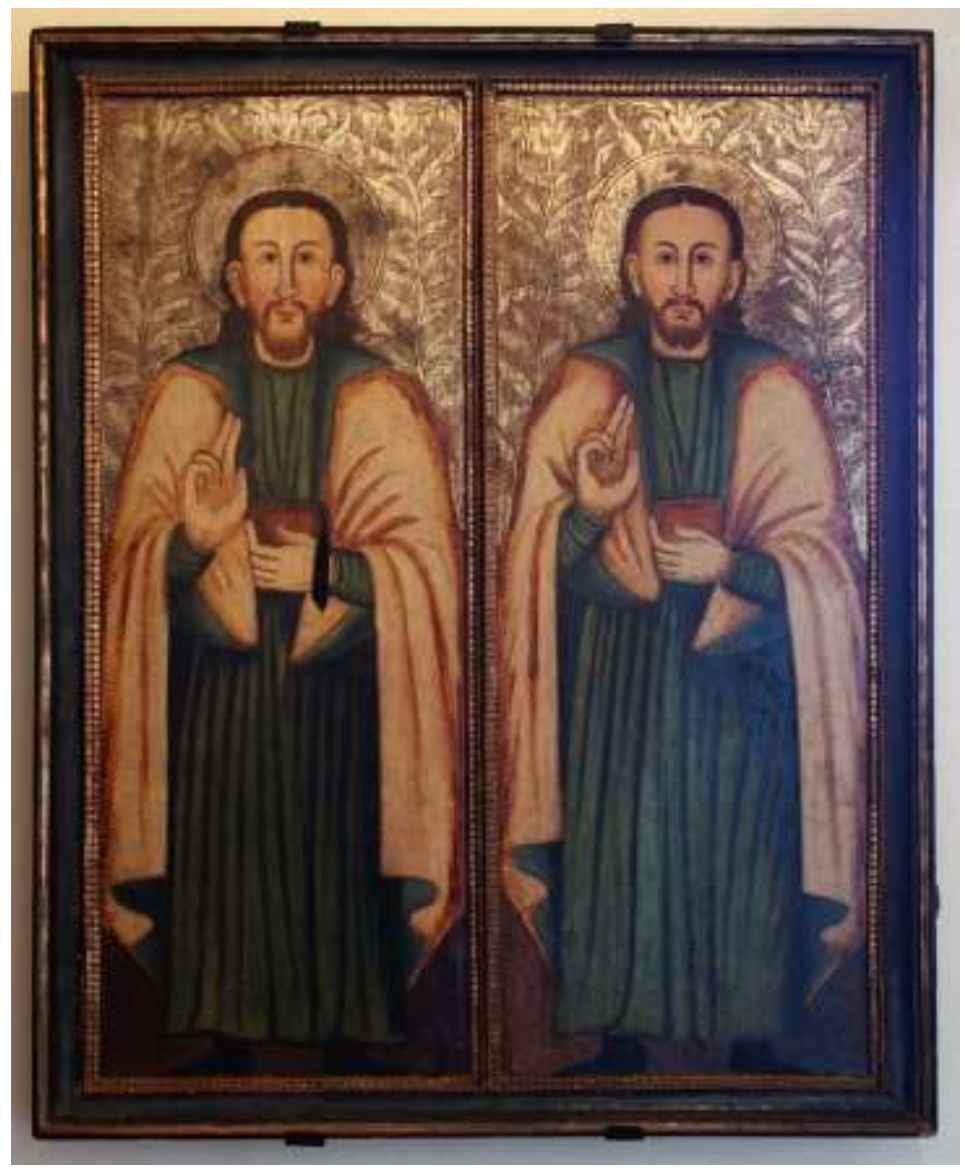

Figure 4: Icon of Saints Cosmas and Damian (17th century, Historical Museum in Sanok).

Their skulls were supposedly moved from Rome to Bremen in the $10^{\text {th }}$ century, and then to Bamberg. In 1581, Charles V's daughter, Mary, gave the skulls to the Poor Clare convent in Madrid, where they are held until today. Other skulls, also said to have been the twins' skulls, were discovered in 1334 by Burchard Grell, the archbishop of Bremen, in a secret hiding place at the choir of the Bremen cathedral $[4,6,8]$. He claimed that the skulls had been brought there from Rome in 965 by Archbishop Adaldaga. Johann Hemeling, a well-known cathedral builder, designed a sanctuary for them, which was finished in 1420 . The chapel was made of oak wood covered with gilded and rolled silver [8]. In 1649, the Lutheran Chapter of Bremen sold the sole sanctuary to Maximilian I of Bavaria. The saints' skulls remained in Bremen and became the property of the Roman Catholic community. In 1934-1968, they were exposed to the public in St. Johann's Church and later, in 1994, buried in the crypt. They are currently placed in St. Michael Jesuit Church in Munich. Another pair of skulls supposedly belonging to the Saints has been stored in St. Stephen's Cathedral in Vienna since at least 1413. Another is kept in San Giorgio Maggiore Church in Venice.

Unfortunately, history is unable to completely verify all that we know about the saint twin brothers. The Orthodox hagiography recognizes as many as three pairs of saint brothers called Cosmas and Damian, all of whom are said to have lived in the same century [16]. The first pair comes from Asia Minor (or possibly Mesopotamia). It is said that these brothers died a martyr's death in the year ca. 300 in Cyprus. This is where their grave is said to be (according to another source in Tamman in Mesopotamia). A feast to their honor is celebrated on November 1.

The second pair of twins (,muczeniki i biessrebreniki Kosma i Damian Arawijskije") is mentioned in Arab sources. They died as martyrs in Cylia in the year 287 or 303 together with three other Christians: Leontius, Anthimus and Eutropius, and an icon with their relics can also be found in Poland in the Orthodox Church of Saint Trinity in Hajnówka. Their feast is celebrated on November 17 and 30.

The third mentioned pair of twins, who treated the ill and propagated Christianity in Rome ruled by Carinus Caesar (250-285), died by the hand of an envious teacher. Their feast is held on 1 July. Perhaps, there were three pairs of twins named Cosmas and Damian and all died during persecution of Christians. But which one was a precursor and which were imitators that adopted identical names? We do not know.

\section{Veneration of Saints Cosmas and Damian}

In the iconography, Cosmas and Damian have always been portrayed together as young or middle-aged men, differing from each other with the length of their beards (Cosmas is the one with the shorter beard). They are dressed in fine robes and colorful cloaks (Cosmas has a red cloak, Damian has an azure one). They are presented with medical instruments, glasses, ointment boxes, scalpels, apothecary spoons, mortars and rod of Asclepius. Since the mid- $13^{\text {th }}$ century, as the professions of a physician and apothecary had been separated, the Western art started assigning them separate specializations and presenting them with different attributes. And so Damian was portrayed as an apothecary with a cylindrical medicine box, while Cosmas was a physician with a diagnostic container for urine [6,10,18] (Figure. 1). Today, Cosmas and Damian are not only patron saints of pharmacists, doctors (especially surgeons), dentists and midwives, but also of hairdressers, physicists, confectioners, manufacturers of chemical substances and sages. They are also patrons of medical faculties, chemical industry, the blind and people with cancer. In 
the United Kingdom, an icon of Damian can be found in the coat of arms of the British Dental Association.

Their main sanctuaries are: Poor Clare convent in Madrid, the basilicas of Santi Cosma e Damiano in Rome, Bitonto and Bari in Italy, and Zočište Monastery in Kosovo. The oldest preserved mosaic with their icons dates back to the $4^{\text {th }}$ and $5^{\text {th }}$ centuries and can be found in the Rotunda of St. George in Thessaloniki. In Prague, at Charles Bridge, there is a monument of Saints Cosmas and Damian holding their professional attributes. In the middle, there is a figure of Christ with the Cross, and the following inscription below: „Jesu Chrust - Orbis Medico” ("To Jesus Christ Doctors of the World"). The monument was raised in 1709 at the initiative of the Faculty of Medicine of the Charles University in Prague and the city's apothecaries (Figure. 5) [8].

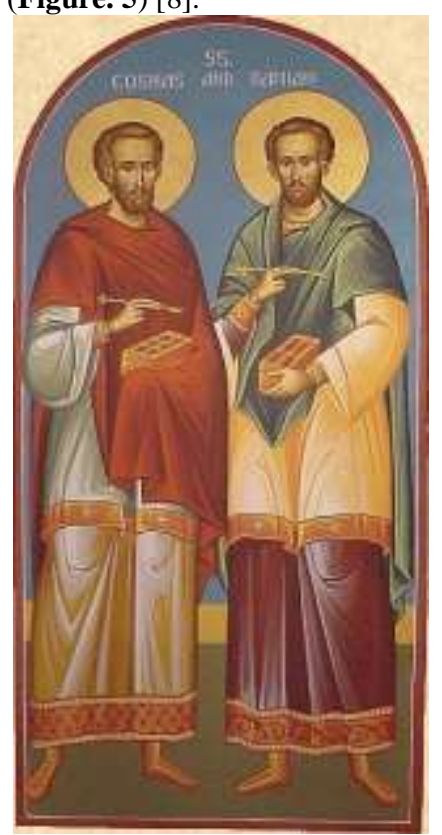

In Poland, according to written sources from 1216, the cult of Saints Cosmas and Damian was observed in a church in Strzelno where the first relics arrived. In 1335, the royal apothecary, Marcin, funded a chapel with the Saints' altar in the Wawel Cathedral, which was mentioned by Jan Długosz more than 100 years later. The chapel was rebuilt in the $16^{\text {th }}$ century and is currently called "Zebrzydowski Chapel." Moreover, there is a document from the $15^{\text {th }}$ century in which the Dean of the Faculty of Medicine of Krakow Academy invites the Faculty members to the Franciscan Church on the day of September 27 where a mass devoted to Saint Cosmas and Damian would be held [6]. In the treasury of Our Holy Lady Mary's Church in Krakow, there is a reliquary of Saints Cosmas and Damian. It is an example of medieval Orthodox art, probably originating from the southern Rus and dating back to the $13^{\text {th }}$ or $16^{\text {th }}$ century. It is a copper gilded box with figural ornamentation with engraved 16 scenes from the saint physicians' lives [17] (Figure. 6).

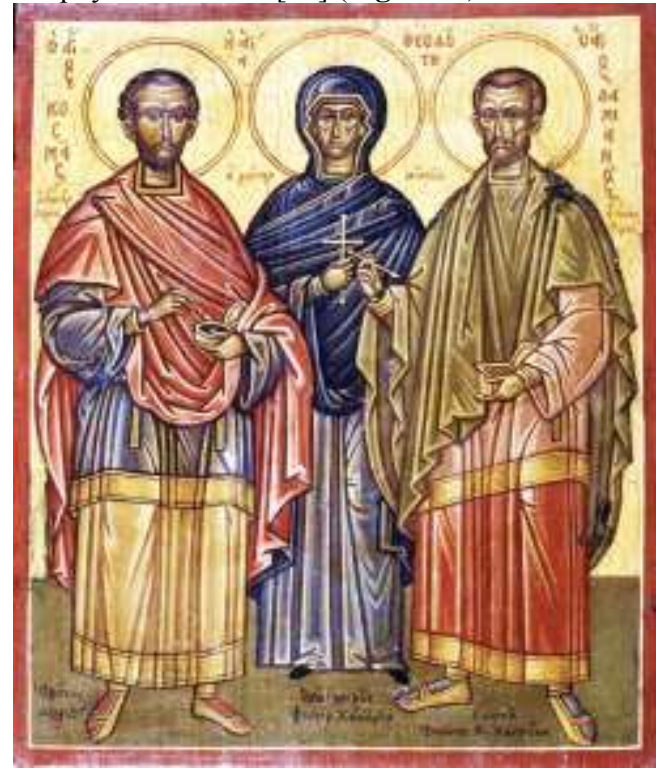

Figure 6: Sts. Cosmas and Damian the Unmercenaries of Asia Minor, with their mother, St. Theodote

(http://0xav8q.bay.livefilestore.com/ylpRUBq 9Hvj6lQ9m8A9aMlah5G LXMWbKcyNka_rbo09XKkpWCnx_Wp326g29eWYkFHcEAiOtaCt 5 UeB w5xHubanyHu5xHubanyHu5xHubanyPGWbKcyNka) Sts. Cosmas and Damian Non-oilers of Asia Minor, with their mother, Saint Theodota

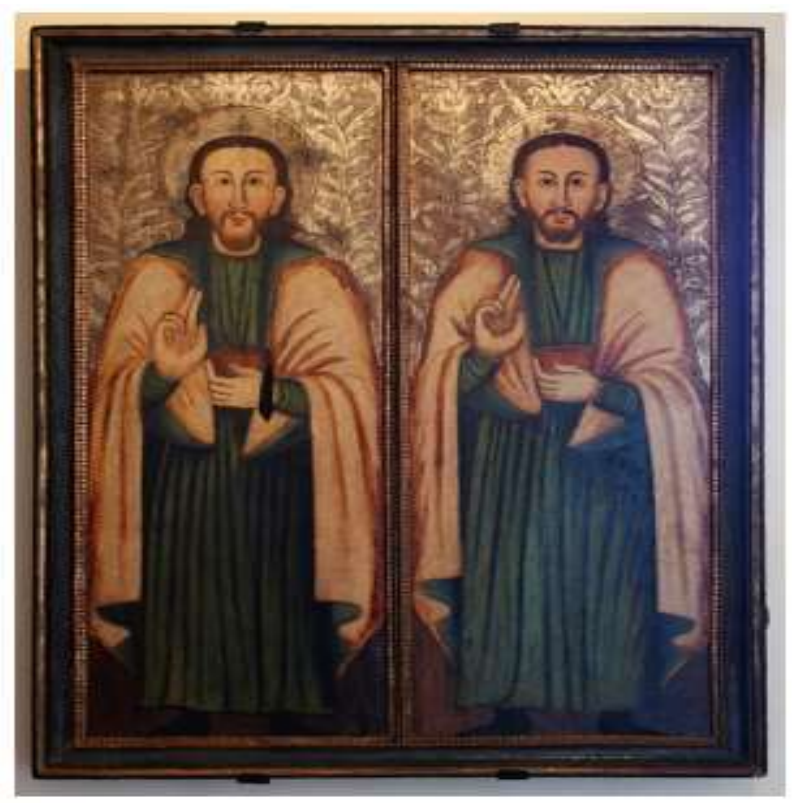

Figure 7: The Icon Museum in Sanok 


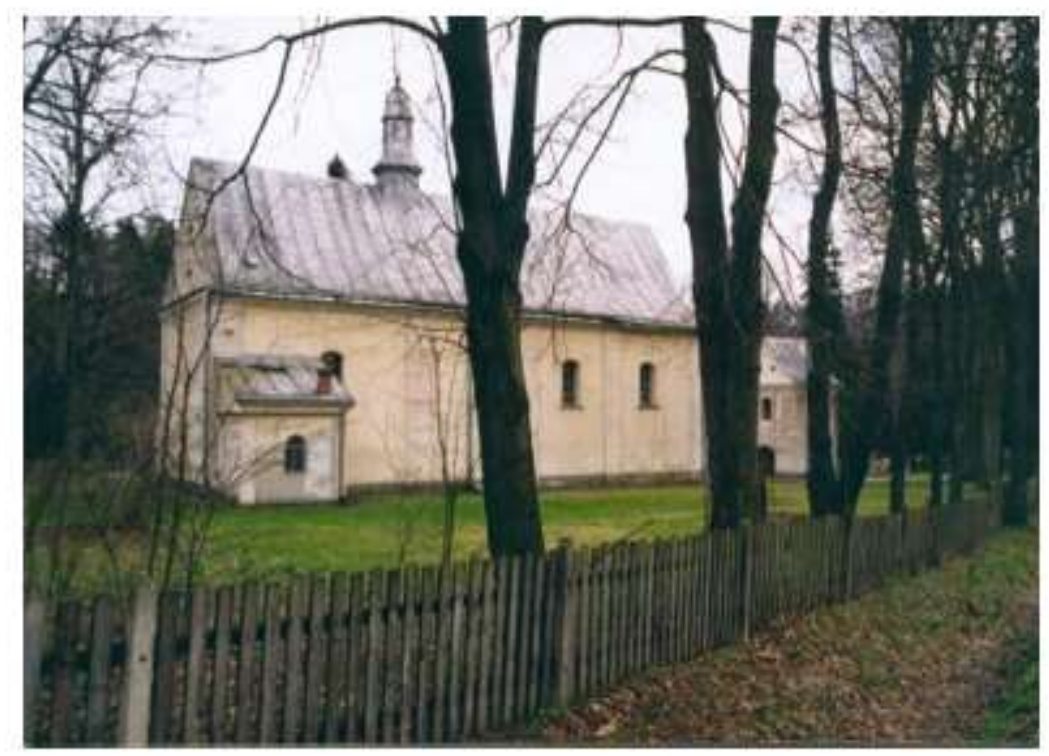

Figure 8: Wujskie - Orthodox church. St. Kosma and Damian (1804)

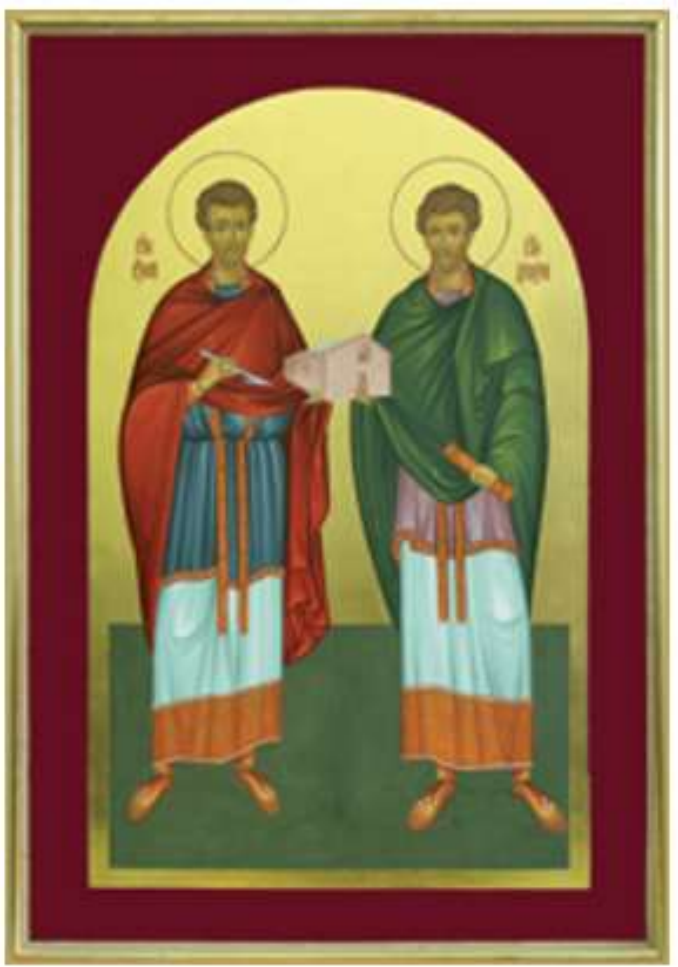

Figure 9: Icon of Kosma and Damian. St. John the Theologian, in Bacieczki in Biatystok. On the icon, the saints do not keep medicine vessels, but a rebuilt monastic church in which healings take place. The icon was painted by monks in Zocziste Kosovo. It is the only such iconographic representation of saint doctors in the world. the icon of Saints Cosmas and Damian, donated on November 27, 2007 to the parish in Bacieczki. 


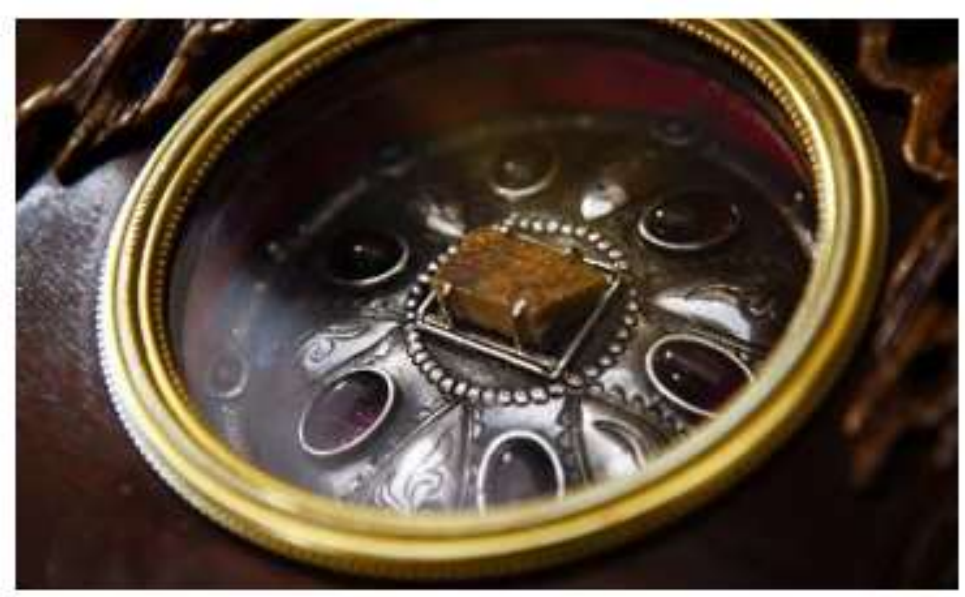

Figure 10: orthodox Church Bacieczka. Relic, fragment of the skull of Saints Cosmas and Damian.
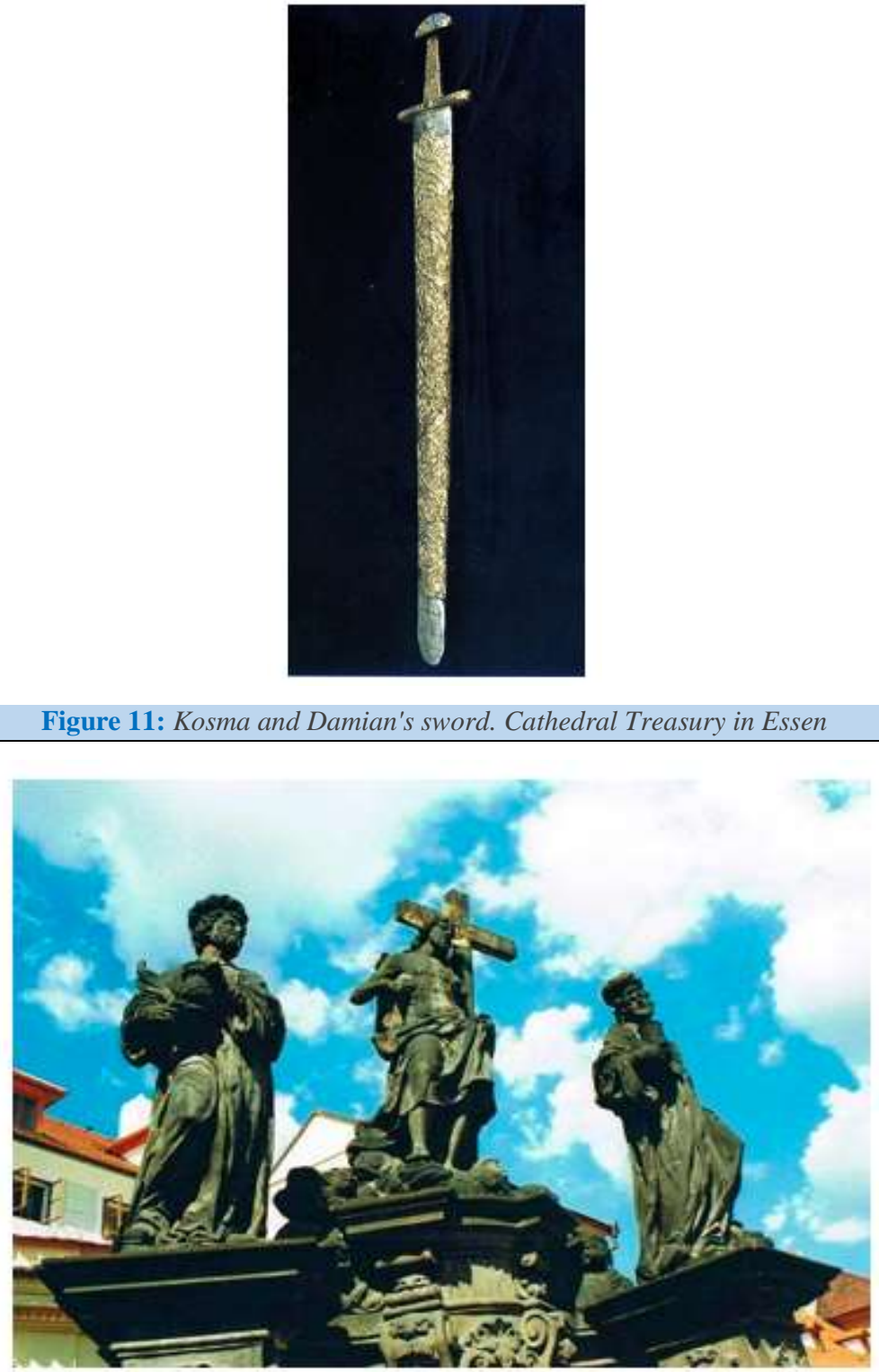

Figure 12: Saints Cosmas and Damian. Monument on the Charles Bridge in Prague. 


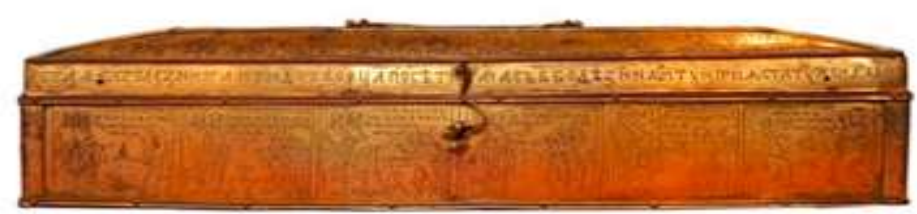

Figure 13: Reliquary of Saints Cosmas and Damian. Treasury of the Church of the Blessed Virgin Mary in Krakow.

In Brazil, the saints are considered protectors of children. On September 27 in Rio de Janeiro, children are given bags of candy with the saints' icons. In Bahia state, Catholics and Candomblé adepts offer caruru meals. According to the tradition, the food is first offered to seven children that are no older than seven years old. Next, the remaining children feast, sitting on the floor and eating with their hands. The food is offered to the remaining guests only after these children finish eating. The Church of Saints Cosme and Damião in Igarassu, Pernambuco, was built in 1535 and is the oldest church in Brazil. Saints Cosmas and Damian are also venerated in Utica, New York at St. Anthony's Parish during the annual pilgrimage that takes place on the last weekend of September (around 27 September). There are thousands of participating pilgrims from different states of the USA and Canada. The two-day festival offers concerts (La Banda Rosa), numerous Italian meals, masses and processions through the streets of East Utica. It is one of the largest festivals devoted to the Saints in the northeast USA. In the Eastern Orthodox Church and Eastern Catholic Churches, Saints Cosmas and Damian are venerated as saint doctors together with other doctors treating with no payment on the first Sunday of November during the feast known as known as Synaxis [8]. In Poland, we have been recently observing a growing interest in Saints Cosmas and Damian. This is mainly associated with a return to the tradition of the Apothecary Feast, celebrated on 26 September.

\section{References}

1. Biblia Tysiąclecia. Pismo Święte Starego i Nowego Testamentu. List do Kolosan. Wydawnictwo Pallottinum w Poznaniu, 2003.

2. Danilevicius Z. SS. Cosmas and Damian. The patron saints of medicine in art. JAMA. 1967;201:1021-5.

3. Dewhurst J. Cosmas and Damian, patron saints of doctors. Lancet. 1988;31:1479-80.

4. Rutt R. Saints Cosmas and Damian: patron saints of medicine. A story from prayers and pictures? J Med Biogr. 1994;2:48-52.

5. Śmierzchalski P, Ząbkowski T. Ikonografia i kult Kosmy i Damiana. Czasopismo Aptekarskie 2013;236-237:21-31.
6. Roeske W. Kosma i Damian w tradycji polskiej medycyny i farmacji. Acta Poloniae Pharmaceutica. 1966;23:581.

7. Biblia Tysiąclecia. Pismo Święte Starego i Nowego Testamentu. Ewangelia wg św. Mateusza. Wydawnictwo Pallottinum w Poznaniu, 2003.

8. Saints Cosmas and Damian. Wikipedia.

9. Norri J. Dictionary of Medical Vocabulary in English, 13751550: Body Parts, Sickness, Instruments, and Medical Preparations. Routledge. Taylor and Francis Group. London and New York. 2016:767.

10. Masiakowski J. Święty Damian prekursorem farmaceuty klinicznego. Magazyn Historyczny Farmacji $i$ Medycyny. 1996;9:2-5.

11. Küppers L, Mikat P. Der Essener Münsterschatz, Essen 1966.

12. Biblia Tysiąclecia. Pismo Święte Starego i Nowego Testamentu. List do Rzymian. Wydawnictwo Pallottinum w Poznaniu, 2003.

13. Jović NJ, Theologou M. The miracle of the black leg: eastern neglect of western addition to the hagiography of Saints Cosmas and Damian. Acta Med Hist Adriat 2015;13;329-344.

14. Kahan BD. Cosmas and Damian revisited. Transplant Proc 1983;15:2211-2217.

15. Masiakowski J. Podobizny Świętych Kosmy i Damiana w Kaplicy Bazyliki Mariackiej w Gdańsku. Pro Memoria. 2006;17:12-14.

16. Werpachowska J. Cerkiew przechowuje bezcenne relikwie świętych lekarzy Kosmy i Damiana. Są uzdrowienia. Internetowy Kurier Poranny. 30 lipca 2011 roku.

17. Zachwieja A. Skrzynka śś. Kosmy i Damiana w skarbcu kościoła NMP w Krakowie, praca magisterska napisana pod kierunkiem prof. Anny Różyckiej-Bryzek w Zakładzie Historii Sztuki Bizantyńskiej w 1995 r. Maszynopis w Archiwum Muzeum Farmacji CM UJ.

18. Kmieć K, Majewski J. Święci Kosma i Damian patroni farmacji jako motyw ekslibrisu. Poznań, Wydawnictwo Kontekst, 2005.
This work is licensed under Creative Commons Attribution 4.0 License

To Submit Your Article Click Here: Submit Manuscript
Ready to submit your research? Choose Auctores and benefit from:

$>$ fast, convenient online submission

$>$ rigorous peer review by experienced research in your field

$>$ rapid publication on acceptance

$>$ authors retain copyrights

$>$ unique DOI for all articles

$>$ immediate, unrestricted online access

At Auctores, research is always in progress.

Learn more https://auctoresonline.org/journals/women-health-care-and-issues 